\title{
Impact of Complex Training on Reaction of Time and Leg Power of Volleyball Athletes
}

\author{
Unun Umaran*, Mohammad Zaky, Iman Imanudin, Herman Subarjah \\ Department of Health and Recreation Education \\ Indonesia University of Education \\ Bandung, Indonesia \\ *ununumaran@upi.edu
}

\begin{abstract}
This study aims to see the meaningful results of the implementation of the Complex Training to increase the ability of reaction time and leg power of UPI volleyball athletes. The method used in this study is an experimental method with the design of One group pretest - posttest design by giving treatment to volleyball athletes totalling 12 people. The data collection process used is an instrument in the form of a test item to determine the reaction time with the whole-body reaction time and to determine the leg power with a vertical jump. Data analysis in this study used SPSS 17 with paired samples t-test. The results showed that the implementation of the training complex had an impact on increasing the reaction time and leg power of volleyball athletes. The application of complex training is a method that can have a significant impact on improving the ability of components of physical conditions. For this reason, the trainers should apply this method appropriately in the training program so that the athlete's abilities can be improved.
\end{abstract}

Keywords: complex training, reaction time, leg power

\section{INTRODUCTION}

Knowledge studies that are currently developing in sporting achievement are related to physical training (Physical Training) whose efforts are how to create a positive impact of training on achievement (performance). As stated by Duthie with research on "Complex, contrast and 'traditional' training" which significantly impact the improvement of jumping abilities [1]. Gourgoulis suggests the results of his research that "presquatting significantly enhanced the vertical jumping ability of stronger participants by $4.01 \%$, but of weaker ones by just $0.45 \% "$ [2]. The results of the study indicate that the development of physical abilities can be maximally improved if it can utilize its application carefully. And, the results of these studies are important to study through research that their application is adapted to the abilities of athletes.

Physical training is a very important part when this training takes place at an elite level, because this is the time to improve physical quality that is very excellent. The many physical components that are needed for athlete achievement require the trainer to try hard to understand well about the training of physical components.

Liossis in his research on the acute effect of upper-body complex training on power output of martial art athletes as measured by the bench press throw exercise, conclude that in complex training, matching a heavy preload stimulus with a longer rest interval, and a lighter preload stimulus with a shorter rest interval is important for athletes wishing to increase their power production before training or competition [3]. Furthermore, Miller in his research on effects of power-based complex training on body composition and muscular strength in collegiate athletes conclude that the current study suggests that the 6-week power-based complex training (PCT) program can positively alter body composition particularly for female athletes and significantly improve upper and lower body strength for both male and female athletes, which will contribute to improvement in athletic performance [4]. From some of the research it is clear that the training carried out appropriately will have an impact on improving the ability of physical conditions.

Many methods and forms of exercise that can be used to improve the physical condition of athletes, such as "Complex Training". This method is rarely or even has never been done in physical training in Indonesia caused by several things, such as some trainers who do not understand the benefits of "Complex Training", equipment that is felt difficult because it requires equipment load, doubts about the implementation of this training activity, and how variation of the exercise. Another thing that becomes a problem in practice is the application of training methods that are still unclear the character of each method. The limitations of the method understood are part of the trainer's limitations in applying the training method. The application of "complex training" is a method that is expected to have a significant impact on the improvement of anaerobic abilities, such as the ability of the speed of movement in the form of speed, agility, or power, as well as the ability to endurance such as speed endurance in the form of speed (speed endurance), agility (agility endurance), and also muscle power that can be maintained for a long time or in a large number of repetitions (power endurance). These issues are intriguing the writer to then be used as strategic steps in further research efforts. Therefore, researchers feel called to examine more deeply about the pattern of "Complex Training" that is varied. Complex training is an exercise to improve strength abilities followed by specific exercises for the branches of the sport, so that it will have a physiological impact on increasing strength and other physical conditions including reaction time and leg power. 
- After that data will be known from each sample

Basically, a volleyball athlete must have good leg power, power is the ability of muscles to direct maximum strength in a very fast time. In addition to the power of a volleyball player must have the ability to fast reaction time, this is because in the game of balls almost all movements require that they react quickly when attacking and when defending. Power and reaction time are needed in sports including volleyball. To increase leg power and reaction time, proper and good practice is needed in its treatment. Good treatment in power training and reaction time so that later to get maximum results, effective and significant training is to use complex training methods. Based on the explanation above, the focus of the research carried out is to describe the impact of complex training on reaction time and leg power of volleyball athletes.

\section{RESEARCH METHODOLOGY}

The research method used in this study is the experimental method. The experimental method is a series of experimental activities with the aim of investigating something or a problem in order to obtain an outcome. So, in the experimental method there must be an experimental activity to see the relationship between the variables studied and tried. The experimental method is used with consideration on the basis of the nature of the study, which is looking at the results of the impact of the application of the complex training method to improving the ability of reaction time and leg power of volleyball athletes.

To provide an overview of the flow of thought in this study the authors provide a description of a research design that I use.

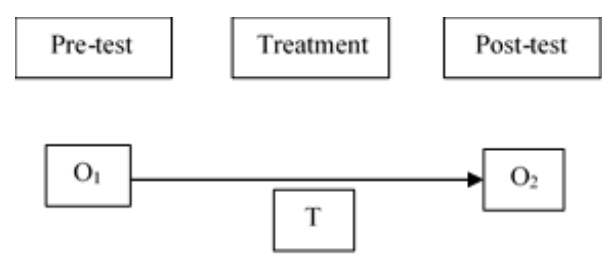

Fig. 1. One group pretest - posttest design [5].

In this study the authors take a population that is a member of the active volleyball student activity unit of Universitas Pendidikan Indonesia totalling 82 people. While the sample is 12 people, the number is taken from male athlete's volleyball student activity unit of Universitas Pendidikan Indonesia who are active and often participate in the championship.

The instrument used to obtain reaction time capability data is whole body reaction time and leg power capability data with vertical jumps.

The steps for implementing the test are as follows:

\section{A. Whole Body Reaction Time}

- The sample stands on a whole-body reaction base

- Look towards the sensor that will emit light

- When the light is on, the sample reacts immediately by opening both feet or jumping left or right

- For each sample doing 5 tests, the best results are taken

\section{B. Vertical Jump}

- The sample stands upright near the wall, the feet are tight, the scale board is on the right / left side of the sample body

- Raise your hands near the wall straight up, palms placed on the scale board until leaving finger marks

- The sample takes the prefix with the knees bent and arms swinging back

- The sample jumps as high as possible while patting the board with the closest hand, causing scars

- The vertical jump test is performed 3 times and the best results are taken as the final result

For data processing analysis, the steps are as follows:

- Set a sample of 12 people, namely male athletes volleyball student activity unit of Universitas Pendidikan Indonesia who are active and often participate in the championship

- Test data normality

- Perform paired samples t-test

- Statistical calculations are performed with the SPSS Series 17 software program.

\section{RESULTS AND DISCUSSION}

After testing the sample that is the ability to test reaction time using the whole-body reaction time and the ability of leg power with a vertical jump, and the results are obtained, the next step is to process the data so that the scores obtained have meaning.

TABLE I. REACTION TIME DATA DESCRIPTION

\begin{tabular}{|l|l|l|l|l|l|l|}
\hline $\begin{array}{c}\text { Sample } \\
\text { Group }\end{array}$ & $\mathbf{N}$ & Average & $\begin{array}{c}\text { Standard } \\
\text { Deviation }\end{array}$ & Variance & $\begin{array}{c}\text { Lowest } \\
\text { score }\end{array}$ & $\begin{array}{c}\text { Highest } \\
\text { Scores }\end{array}$ \\
\hline $\begin{array}{l}\text { Pre test } \\
\text { reaction } \\
\text { time }\end{array}$ & 12 & 0,3265 & 0,0497 & 0,002 & 0,41 & 0,22 \\
\hline $\begin{array}{l}\text { Post test } \\
\text { reaction } \\
\text { time }\end{array}$ & 12 & 0,2272 & 0,0189 & 0,001 & 0,27 & 0,20 \\
\hline
\end{tabular}

Description of the reaction time capability data can be seen that the average post-test group reaction time is faster than the average pre-test group. It can be assumed that the post-test group has better reaction time ability than the pre-test group.

TABLE II. LEG POWER DATA DESCRIPTION

\begin{tabular}{|l|l|l|l|l|l|l|}
\hline $\begin{array}{c}\text { Sample } \\
\text { Group }\end{array}$ & $\mathbf{N}$ & Average & $\begin{array}{c}\text { Standard } \\
\text { Deviation }\end{array}$ & Variance & $\begin{array}{c}\text { Lowest } \\
\text { score }\end{array}$ & $\begin{array}{c}\text { Highest } \\
\text { Scores }\end{array}$ \\
\hline $\begin{array}{l}\text { Pre test } \\
\text { leg power }\end{array}$ & 12 & 60,08 & 5,79 & 33,54 & 49,20 & 70,00 \\
\hline $\begin{array}{l}\text { Post test } \\
\text { leg power }\end{array}$ & 12 & 67,04 & 4,20 & 17,66 & 60,00 & 74,00 \\
\hline
\end{tabular}


Furthermore, the description of leg power ability data can be seen that the average post-test power of the limbs is higher than the average pre-test group. It can be assumed that the posttest group has better leg power ability compared to the pre-test group.

The first step taken before testing the hypothesis is to test the normality, the results are as follows:

TABLE III. CAPABILITy DATA NORMALITY TEST RESUlts REACTION TIME AND LEG POWER

\begin{tabular}{|l|c|c|c|c|c|c|}
\hline & \multicolumn{3}{|c|}{ Kolmogorov-Smirnov ${ }^{\text {a }}$} & \multicolumn{3}{|c|}{ Shapiro-Wilk } \\
\cline { 2 - 7 } & $\begin{array}{c}\text { Stati } \\
\text { stic }\end{array}$ & df & Sig. & $\begin{array}{c}\text { Statisti } \\
\text { c }\end{array}$ & df & Sig. \\
\hline Pree_Test_reaction time &, 167 & 12 &, $200^{*}$ &, 948 & 12 &, 605 \\
\hline Post_Test_reaction time &, 187 & 12 &, $200^{*}$ &, 913 & 12 &, 235 \\
\hline \multicolumn{4}{|c|}{ *. This is a lower bound of the true significance. } \\
\hline
\end{tabular}

TABle IV. CAPability Data Normality Test Results Leg Power

\begin{tabular}{|l|l|l|l|l|l|c|}
\hline & \multicolumn{3}{|c|}{ Kolmogorov-Smirnov ${ }^{\text {a }}$} & \multicolumn{3}{c|}{ Shapiro-Wilk } \\
\cline { 2 - 7 } & Statistic & df & Sig. & $\begin{array}{c}\text { Statist } \\
\text { ic }\end{array}$ & df & Sig. \\
\hline Pree_Test_Leg Power_ &, 112 & 12 &, $200^{*}$ &, 982 & 12 &, 990 \\
\hline $\begin{array}{l}\text { Post_Test_Leg } \\
\text { Power }\end{array}$ &, 103 & 12 &, $200^{*}$ &, 976 & 12 &, 964 \\
\hline \multicolumn{6}{|c|}{ *. This is a lower bound of the true significance. } \\
\hline
\end{tabular}

The probability value (Sig.) For the pre-test reaction time based on the Kolmogorov Smirnov test is 0.200 greater than 0.05 . Likewise, for the post-test reaction time tested using Kolmogorov Smirnov analysis, the probability value (Sig.) of 0.200 is greater than 0.05 . Refers to the provision that, if the probability or significance value is greater than 0.05 , then the data is normally distributed.

Furthermore, the probability value (Sig.) for the pre-test of leg power based on the Kolmogorov Smirnov test is 0.200, greater than 0.05. And for the post-test of leg power tested using Kolmogorov Smirnov analysis, the probability value (Sig.) of 0.200 is greater than 0.05. Refers to the provision that, if the probability or significance value is greater than 0.05 , then the data is normally distributed.

Based on the results of the analysis of these data, it can be concluded that the capability data of reaction time and leg power are at the level of Normal distribution. Thus, testing for reaction time and leg power data uses parametric statistical testing because the data is normally distributed.

Furthermore, the data obtained were calculated using a paired sample t test, which is to determine the effect or impact of complex training on reaction time and leg power. The results are as follows:
TABLE V. Paired SAmples Test Results t-TEST Reaction Time CAPABILITY

\begin{tabular}{|c|c|c|c|c|c|c|c|c|}
\hline & \multicolumn{5}{|c|}{ Paired Differences } & \multirow[t]{3}{*}{$\mathbf{T}$} & \multirow[t]{3}{*}{ df } & \multirow{3}{*}{$\begin{array}{c}\text { Sig. } \\
(2- \\
\text { tailed) }\end{array}$} \\
\hline & \multirow[t]{2}{*}{$\begin{array}{c}\text { Mea } \\
n\end{array}$} & \multirow[t]{2}{*}{$\begin{array}{c}\text { Std. } \\
\text { Deviat } \\
\text { ion }\end{array}$} & \multirow[t]{2}{*}{$\begin{array}{c}\text { Std. } \\
\text { Error } \\
\text { Mean }\end{array}$} & \multicolumn{2}{|c|}{$\begin{array}{c}95 \% \\
\text { Confidence } \\
\text { Interval of the } \\
\text { Difference }\end{array}$} & & & \\
\hline & & & & Lower & Upper & & & \\
\hline $\begin{array}{l}\text { Pre_TestReaction } \\
\text { Time } \\
\text { Post_Test_Reacti } \\
\text { on_Time }\end{array}$ & $\begin{array}{l}, 099 \\
33\end{array}$ & 03942 & ,01138 & ,07429 & , 12438 & $\begin{array}{l}8,7 \\
30\end{array}$ & 11 & ,000 \\
\hline
\end{tabular}

TABLE VI. PAIRED SAMPles Test Results T-TeSt AND LEG POWER

\begin{tabular}{|c|c|c|c|c|c|c|c|c|}
\hline & \multicolumn{5}{|c|}{ Paired Differences } & \multirow[t]{3}{*}{$\mathbf{t}$} & \multirow[t]{3}{*}{ df } & \multirow{3}{*}{$\begin{array}{l}\text { Sig. } \\
(2- \\
\text { tailed })\end{array}$} \\
\hline & \multirow[t]{2}{*}{$\begin{array}{c}M e \\
\text { an }\end{array}$} & \multirow[t]{2}{*}{$\begin{array}{c}\text { Std. } \\
\text { Deviat } \\
\text { ion }\end{array}$} & \multirow[t]{2}{*}{$\begin{array}{c}\text { Std. } \\
\text { Error } \\
\text { Mean }\end{array}$} & \multicolumn{2}{|c|}{\begin{tabular}{|c|}
$95 \%$ \\
Confidence \\
Interval of the \\
Difference \\
\end{tabular}} & & & \\
\hline & & & & Lower & Upper & & & \\
\hline $\begin{array}{l}\text { Pree_Test_Leg_P } \\
\text { ower } \\
\text { Post_Test_Leg_P } \\
\text { ower }\end{array}$ & $\begin{array}{l}- \\
6,95 \\
833\end{array}$ & $\begin{array}{l}2,1802 \\
7\end{array}$ & ,62939 & \begin{tabular}{|l|}
- \\
8,3436 \\
1
\end{tabular} & $\begin{array}{l}- \\
5,5730 \\
6\end{array}$ & $\begin{array}{l}- \\
11 \\
056\end{array}$ & 11 & ,000 \\
\hline
\end{tabular}

t-value of reaction time is 8.730 with probability (Sig.) 0.00 . Because the probability (Sig.) $0.00<0.05$ then $\mathrm{HO}$ is rejected. This means that there is a significant effect of complex training on reaction time. Furthermore, for the t-value of leg power is 11,056 with a probability (Sig.) 0.00. Because the probability (Sig.) $0.00<0.05$ then H0 is rejected. This means that there is a significant effect of complex training on leg power.

Based on the results of this processing, it can be concluded that complex training has a positive influence or impact on the ability of reaction time and leg power of volleyball athletes at Indonesia University of Education.

This is in line with what was stated by Brad Mc Gregor that "The increasing emphasis on athletics and sporting success has prompted scientists to investigate various training methods that can have a positive effect on performance [6]. One method that received significant attention was complex training. So it is clear that the application of complex training methods provided will have a positive impact to improve the ability of physical components, such as the ability of the speed of motion, and strength, and also the ability to function speed endurance such as speed endurance in the form of speed (speed endurance), agility (agility endurance), and also muscle strength that can determine a long time or in a number of repetitions (endurance endurance).

\section{CONCLUSIONS}

Based on the results of data processing and analysis that the authors have done; it can be concluded from the results of the study. This is based on the facts and data that the author obtained, the conclusion is that complex training has an effect on the ability of reaction time and leg power of volleyball athletes. This is evidenced by the results of the post-test the ability of reaction time and leg power possessed by volleyball athletes is better than the pre-test. Thus, complex training provides a significant increase in reaction time and leg power. The application of complex training is a method that can have a 
athletes," American Journal of Sports Science and Medicine, vol. 2(5), pp.202-207, 2014.

impact on improving the ability or physical conditions [7-9]. For this reason, the trainers should apply this method appropriately in the training program so that the athlete's abilities can be improved $[10,11]$.

\section{REFERENCES}

[1] G.M. Duthie, W.B. Young, and D.A. Aitken, "The acute effects of heavy loads on jump squat performance: An evaluation of the complex and contrast methods of power development," The Journal of Strength \& Conditioning Research, vol. 16(4), pp. 530-538, 2002.

[2] V. Gourgoulis, N. Aggeloussis, P. Kasimatis, G. Mavromatis, and A. Garas, "Effect of a submaximal half-squats warm-up program on vertical jumping ability," The Journal of Strength \& Conditioning Research, vol. 17(2), pp. 342-344. 2003.

[3] L.D. Liossis, J. Forsyth, C. Liossis, and C. Tsolakis, "The acute effect of upper-body complex training on power output of martial art athletes as measured by the bench press throw exercise," Journal of human kinetics, vol. 39(1), pp.167-175, 2013.

[4] J. Miller, Y. Koh, and C.G. Park, "Effects of power-based complex training on body composition and muscular strength in collegiate
[5] J.R. Fraenkel, N.E. Wallen, "How To Design and Evaluate Research in Education," USA: McGraw Hill, Inc, 1993.

[6] B. McGregor, "The application of complex training for the development of explosive power," J Strength Cond Res, vol. 12(1), pp. 15-25. 2006

[7] D. Docherty, D. Robbins, and M. Hodgson, "Complex training revisited: A review of its current status as a viable training approach," Strength and Conditioning Journal, vol. 26(6), p. 52, 2004.

[8] E.J. Santos, and M.A. Janeira, "Effects of complex training on explosive strength in adolescent male basketball players," The Journal of Strength \& Conditioning Research, vol. 22(3), pp. 903-909, 2008.

[9] J.P. Mihalik, J.J. Libby, C.L. Battaglini, and R.G. McMurray, "Comparing short-term complex and compound training programs on vertical jump height and power output," The Journal of Strength \& Conditioning Research, vol. 22(1), pp. 47-53, 2008.

[10] L. Ingle, M. Sleap, and K. Tolfrey, "The effect of a complex training and detraining programme on selected strength and power variables in early pubertal boys," Journal of sports sciences, vol. 24(9), pp. 987-997, 2006.

[11] J.M.V.M. Alves, A.N. Rebelo, C. Abrantes, and J. Sampaio, "Short-term effects of complex and contrast training in soccer players' vertical jump, sprint, and agility abilities," The Journal of Strength \& Conditioning Research, vol. 24(4), pp. 936-941, 2010. 